\title{
Analisis Kesantunan Proses Komunikasi Mahasiswa dengan Dosen melalui Aplikasi Whatsapp terhadap Efektifitas Penggunaan Bahasa
}

\author{
Nurfaedah, Suwatri Jura \\ STMIK Handayani Makassar \\ nurfaedahkimya@handayani.ac.id,suwatrijura@handayani.ac.id
}

\begin{abstract}
Abstrak
Penelitian ini bertujuan menganalisis bentuk pelanggaran prinsip kesantunan proses komunikasi mahasiswa dengan dosen melalui aplikasi pesan whatsapp terhadap efektifitas penggunaan bahasa. Penelitian ini meupakan penelitian kualitatif. Data penelitianberupa data tulisan yang dikmpulkan dengan menggunakan metode dokumentasi, transkripsi dan teknik catat. Analisis data dilakukan secara deskriptif sesuai denganteori kesantunan Leech. Hasil penelitian menunjukkan bahwa Pelanggaran terhadap prinsip kesantunan Leech meliputi 4 maksim. Pelanggaran secara berturut-turut dilakukan terhadap maksim kebijaksanaan, maksim pemufakatan, maksim kedermawanan, dan maksim kesederhanaan. Pelanggaran maksim ini pada proses komunikasi mahasiswa melalui pesan whatsapp menandakan bahwa masih ada indikasi yang membuat mahasiswa tidak santun dalam melakukan komunikasi dengan dosen dalam media online. Pelanggaran kesantunan mahasiswa mempengaruhi keefektifan berbahasa mahasiwa pada proses komunikasi, dan keefektifan itu dibahas dalam tiga jenis yaitu keutuhan kalimat, kelogisan dan ketepatan diksi.

Kata kunci: Pelanggaran Kesantunan, Efektifitas berbahasa mahasiswa, whatsapp
\end{abstract}

\section{Pendahuluan}

Dalam berkomunikasi, baik komunikasi verbal maupun non-verbal kesantunan berbahasa sangat perlu dipahami oleh pengguna bahasa. Berbahasa tidak hanya sekedar menyampaikan ide dan gagasan, tetapi juga bagaimana menggunakan bahasa yang baik dan benar. Dalam hal ini penggunaan bahasa disesuaikan dengan situasi dan konteks kapan dan di mana bahasa itu dituturkan. Jika pengguna bahasa tidak memahami bagaimana berbahasa yang baik, maka komunikasi yang terbangun tidak akan efektif.

Kesantunan merupakan norma atau aturan perilaku yang ditetapkan dan disepakati bersama oleh suatu masyarakat tertentu yang dipengaruhi oleh tata cara, adat ataupun kebiasaan yang berlaku dalam masyarakat. Kesantunan dipengaruhi oleh adanya konteks serta peran yang terlibat dalam komunikasi itu sendiri. Konteks berkaitan dengan tempat, waktu, atau suasana yang melatarbelakangi terjadinya komunikasi. Peran berkaitan dengan usia, kedudukan, atau status sosial dari penutur dan mitra tutur selama berlangsungnya proses komunikasi.

Kecanggihan teknologi memberikan dampak positif dalam penyebaran informasi. Informasi dapat diperoleh dengan cepat melalui berbagai media yang tersedia di situs jejaring online. Salah satunya adalah melalui aplikasi pesan Whatsapp. Kegiatan berkomunikasi menjadi lebih mudah dan cepat karena dapat berinteraksi langsung tanpa harus bertatap muka. Untuk kalangan mahasiswa komunikasi sudah marak menggunakan aplikasi Whatsapp dan menjadi salah satu alternatif alat komunikasi. Ketika ingin berkomunikasi dengan dosen secara langsung dan cepat seperti saat ingin membuat janji temu dengan dosen, melakukan konsultasi atau bimbingan skripsi, ijin tidak bisa mengikuti perkuliahan, mengingatkan jadwal perkuliahan, seminar dan ujian. 
Dalam hubungannya dengan kesantunan berbahasa ini, banyak ditemukan perilaku berbahasa mahasiswa yang melanggar norma kesopanan dalam berbahasa ketika berinteraksi dengan dosen. Mahasiswa sering kurang menyadari bahwa bahasa yang mereka gunakan sering membuat dosen merasa tidak nyaman. Pilihan kata yang digunakan oleh mahasiswa terkadang tidak mempertimbangkan konteks situasi beserta kondisi di mana bahasa itu dituturkan. Penggunaan media Whatsapp dalam berkomunikasi dengan dosen membuat mahasiswa secara langsung menggunakan bahasa yang santai dan tidak sesuai dengan norma kesopanan.

Beberapa aturan harus diperhatikan seseorang ketika menuturkan setiap tuturannya baik secara lisan maupun tulisan yakni penerapan prinsip kerja sama diantaranya dengan memperhatikan maksim kuantitas, maksim kualitas, maksim relevansi dan maksim cara. Selain penerapan prinsip kerja sama, tetapi harus memperhatikan yang berkenaan dengan kesantunan berbahasa, apalagi pesan ditujukan pada orang yang lebih tua atau dihormati. Komunikasi antar mahasiswa terhadap dosen perlu mendapat perhatian lebih, karena menyangkut kesantunan dalam berbahasa. Mahasiswa dalam berkomunikasi harus memahami hal-hal yang perlu diperhatikan dalam menghubungi dosen. Bahasa yang digunakan mencerminkan bagaimana perlakuan dan sikap penutur terhadap bahasa. Etika harus tetap dijaga, sehingga tidak terjadi hal-hal yang sama-sama tidak diinginkan. Prinsip-prinsip kesantuan tetap harus diperhatikan agar proses komunikasi yang baik bisa terjalin.

Dalam menghubungi dosen pada percakapan tulisan perlu diperhatikan hal-hal berikut: pertama mahasiswa diimbau memilih waktu yang tepat untuk menghubungi dosen, kedua mengawali dengan sapaan atau ucapan salam, menyebutkan identitas, menggunakan bahasa yang umum, menuliskan pesan dengan jelas, dan mengucapkan terima kasih. Namun banyak mahasiswa yang tidak menyadari hal tersebut dan terkadang pilihan kata yang digunakan kerap kali membuat dosen merasa bahwa mahasiswa kurang sopan dan tidak tau etika. Selain itu cara mahasiswa menyampaikan pesannya dapat menggambarkan bagaimana kemampuan mereka dalam berbahasa.

Lebih lanjut penelitian ini bertujuan mendeskripsikan kesantunan berbahasa mahasiswa dalam berkomunikasi dengan dosen melalui aplikasi Whatsapp serta bagaimana hubungannya dengan efektifitas penggunaan bahasa mahasiswa.

Berdasarkan uraian di atas, dipandang perlu melaksanakan penelitian untuk menganalisis kesantunan proses komunikasi mahasiswa dengan Dosen melalui aplikasi Whatsapp terhadap efektifitas penggunaan bahasa mahasiswa di STMIK Handayani Makassar.

\section{Teori Kesantunan}

Kesantunan berbahasa adalah hal memperlihatkan kesadaran akan martabat orang lain dalam berbahasa, baik menggunakan bahasa lisan maupun bahasa tulis. Santun bukan hanya sekedar diperlihatkan dengan tingkah laku namun santun juga harus disesuaikan dengan tutur bahasa yang baik. Tuturan akan disebut santun apabila peserta tutur tidak terdengar memaksa dan memperhatikan kata-kata serta bahasa yang akan disampaikan kepada lawan tutur. Kesantunan merupakan aturan perilaku yang ditetapkan dan disepakati bersama oleh suatu masyarakat tertentu sehingga kesantunan sekaligus menjadi prasyarat yang disepakati oleh perilaku social (Yule, 1996:104). 
Robin Lakof mengembangkan teori kesantunan yang berbunyi jika tuturan kita ingin terdengar santun ditelinga pendengar atau lawan tutur kita ada tiga kaidah yang harus dipatuhi, yaitu formalitas (formality) jangan memaksa atau angkuh (aloof), ketidak tegasan (hesitancy), buatlah sedemikian rupa sehingga lawan tutur dapat menentukan pilihan (option), dan persamaan atau kesekawanan (equality or camaraderie), bertindaklah seolaholah Anda dan lawan tutur Anda menjadi sama (Chaer, 2010:46).

Teori kesantuana Bruce Fraser, yang mengatakan bahwa kesantunan dalah properti yang diposisikan dengan tuturan dan di dalam hal ini menurut pendapat lawan tutur, bahwa si penutur tidak melampaui hak-haknya atau tidak mengingkari dalam memenuhi kewajibannya. Sedangkan penghormatan adalah bagian dari aktivitas yang berfungsi sebagai sarana simbolis untuk menyatakan penghargaan secara regular (Chaer, 2010:47).

Tarigan (2009:46) salah satu cara menghasilkan kesopansantunan adalah menjaga kesamaan isi proporsional $\mathrm{x}$ dan mempertinggi taraf kesopansantunan dengan mempergunakan banyak lagi ilokusi tidak langsung. Ilokusi tidak langsung lebih cenderung sopan karena dua hal yaitu ilokusi tak langsung itu meniggikan taraf kefakultarifan dan semakin tidak langsung ilokusi semakin berkurang tentative pula keperluannya.

Sementara Rahardi (2005:35) menjelaskan bahwa penelitian kesantuan termasuk dalam kajian penggunaab bahasa dalam suatu masyarakat tertentu. Masyarakat memiliki kultur daerah yang berbeda latar belakang dengan mengindah-kan suatu maksud atau tujuan daru tutran tersebut. Menurut KBBI santun adalah halus dan baik budi bahasanya, tingkah lakunya; sopan, sabar dan tenang.

Berdasarkan beberapa pendapat di atas, penulis dapat menyimpulkan bahwa kesantunan adalah sikap yang terdiri dari sikap berbahasa dan sikap bertingkah laku yang didorong oleh rasa saling menghargai dan menghormati pada lawan tutur dalam menyampaikan maksud tertentu. Sehingga pada akhirnya komunikasi yang berjalan dapat sampai kepada tujuan yang diinginkan dengan tidak melanggar kepatuhan akan norma dalam berbahasa untuk mewujudkan masyarakat yang bersinergi antara sikap dan bahasa sebagai wujud budaya yang beradab.

Salah satu teori yang digunakan oleh penulis yaitu dari Leech. Prinsip kesantunan Leech ini didasarkan pada kaidah-kaidah. Kaidah-kaidah ini berupa maksim-maksim, dan maksim-maksim ini menganjurkan agar kita mengunkapkan keyakinan-keyakinan yang sopan dan bukan keyakinan-keyakinan yang tidak sopan (Leech, 1993:207). Kaidah-kaidah itu tak lain adalah prnsip-prinsip yang berisi nasehat yang harus dipatuhi agar tuturan penutur memenuhi prinsip kesantunan. Leech (1993:206) membagi prinsip-prinsip kesantunan tersebut menjadi enam, yaitu:

\section{Maksim Kebijaksanaan (Tact Maxim)}

(1) Buatlah kerugian orang lain sekecil mungkin.

(2) Nuatlah keuntungan orang lain sebesar mungkin.

Gagasan dasar dalam maksim kebijaksanaan dalam prinsip kesantunan adalah para peserta pertuturan hendaknya berpegang pada prinsip untuk selalu mengurangi keuntungan dirinya sendiri dan memaksimalkan keuntungan pihak lain dalam kegiatan berutur. Orang bertutur yang berpegang dan melaksanakan maksim kebijaksanaan akan dapat dikatakan sebagai orang yang santun. Contoh :

- Tuan rumah : "silakan makan saja dulu, Nak! Tadi kami semua sudah mendahului." 
Jurnal Onoma: Pendidikan, Bahasa dan Sastra

Volume 6 Nomor 2

- Tamu : "Wah, saya jadi tidak enak, Bu."

Informasi Indeksial:

Dituturkan oleh seorang ibu kepada seorang anak muda yang sedang bertamu di rumah ibu tersebut. Pada saat itu, ia harus berada di rumah ibu tersebut sampai malam karena hujan sangat deras dan tidak segera reda.

Maksim Kedermawanan (Generosity Maxim)

(1) Buatlah keuntungan diri sendiri sekecil mungkin.

(2) Buatlah kerugian diri sendiri sebesar mungkin.

Dasar maksim kedermawanan atau maksim mekurahan hati adalah para peserta pertuturan diharapkan dapat menghormati orang lain. Penghormatan kepada orang lain akan terjadi apabila orang dapat mengurangi keuntungan bagi dirinya sendiri dan memaksimalkan keuntungan bagi pihak lain. Contoh :

- Anak Kos A : "Mari saya cucikan baju kotormu! Pakainku tidak banyak, kok, yang kotor."

- Anak Kos B : “Tidak usah, Mbak. Nanti siang saya akan mencuci juga, kok!” Informasi Indeksial:

Tuturan ini merupakan cuplikan pembicaraan antar anak Kos pada sebuah rumah kos di Yogjakarta. Anak yang satu (A) berhubungan demikian erat dengan anak yang lainnya (B).

Dari tuturan yang disampaikan si (A), dapat dilihat dengan jelas bahwa ia berusaha memaksimalkan keuntungan pihak lain dengan cara menambahkan beban bagi dirinya sendiri. Orang yang tidak suka membantu orang lain, apalagi tidak pernah bekerja bersama orang lain, akan dapat dikatakan tidak sopan dan biasanya tidak akan mendapatkan teman di dalam pergaulan kesehariannya.

\section{Maksim Penghargaan (Approbation Maxim)}

(1) Kecamlah orang lain sesedikit mungkin

(2) Pujilah orang lain sebanyak mungkin

Maksim penghargaan menjelaskan bahwa orang akan dapat dianggap santun apabila dalam berututur selalu berusaha memberikan penghargaan dari pihak lain. Dengan maksim ini, diharapkan agar para peserta pertuturan tidak saling mengejek, saling mencaci, atau saling merendahkan pihak lain. Contoh :

- Dosen A : "Pak, aku tadi sudah memulai kuliah perdana untuk kelas Bussines English."

- Dosen B : “Oya, tadi aku mendengar Bahasa Inggrismu jelas sekali dari sini.”

Informasi Indeksial:

Dituturakan oleh seorang dosen kepada temannya yang juga seorang dosen dalam ruang kerja dosen pada sebuah perguruan tinggi. Pemberitahuan yang disampaikan dosen A terhadap rekannya dosen $B$, ditanggapi dengan sangat baik bahkan disertai pujian atau penghargaan oleh dosen B. dengan demikian, dapat dikatakan bahwa di dalam pertuturan itu, dosen B berprilaku santun.

\section{Maksim Kesederhanaan (Modesty Maxim)}

(1) Pujilah diri sendiri sesedikit mungkin.

(2) Kecamlah diri sendiri sebanyak mungkin. 
Volume 6 Nomor 2

Pada maksim kesederhanaan peserta tutur diharapkan dapat bersikap rendah hati dengan cara mengurangi pujian terhadap dirinya sendiri. Dalam masyarakat bahasa dan budaya Indonesia, kesederhanaan dan kerendahan hati banyak digunakan sebagai parameter penilaian kesantunan seseorang. Contoh:

- Sekretaris A : "Dik, nanti rapatnya dibuka dengan doa dulu, ya!"

- Sekretaris B : "Ya, Mbak. Tapi saya jelek, lho."

Informasi Indeksial:

Dituturkan oleh seorang sekretaris kepada sekretaris lain yang masih junior pada saat mereka bersama-sama bekerja di ruang kerja mereka. Dari tuturan sekretaris B, dapat terlihat bahwa dia bersikap rendah hati dan mengurangi pujian untuk dirinya sendiri. Dengan demikian, tuturan tersebut terasa santun.

\section{Maksim Pemufakatan (Agreement Maxim)}

(1) Usahakan agar ketaksepakatan antara diri dan orang lain terjadi sesedikit mungkin.

(2) Usahakan agar kesepakatan antara diri dan orang lain terjadi sebanyak mungkin. Maksim ini menekankan agar para peserta tutur dapat saling membina kecocokan atau kemufakatan di dalam kegiatan berutur. Apabila terdapat kemufakatan atau kecocokan antara diri penutur dan mitra tutur dalam kegiatan bertutur, masing-masing dari mereka akan dapat dikatan bersikap santun. Contoh :

- Noni : "nanti malam kita makan ya, Yun!"

- Yuyun : "Boleh. saya tunggu di bamboo resto." Informasi Indeksial:

Dituturkan oleh mahasiswa kepada temannya yang juga mahasiswa pada saat mereka sedang berada di sebuah ruang kelas. Tuturan tersebut terasa santun karena Yuyun mampu membina kecocokan dengan Noni. Dengan memaksimalkan kecocokan diantara mereka tuturan akan menjadi santun.

\section{Maksim Kesimpatian (Shimpaty Maxim)}

(1) Kurangi rasa antipati antara diri dengan orang lain hingga sekecil mungkin

(2) Tingkatkan rasa simpati sebanyak-banyakanya antara diri dan orang lain.

Sikap antipati kepada salah seorang peserta tutur akan dianggap sebagai tindakan yang tidak santun. Orang yang bersikap antipati terhadap orang lain, apalagi sampai bersikap sinis terhadap pihak lain, akan dianggap sebagai orang yang tidak tahu sopan santun di dalam masyarakat. Contoh :

- Ani : "Tut, nenekku meninggal."

- Tuti : "Innalillahi Wainnailaihi Rojiun, saya turut berduka cita, Ani."

Informasi Indeksial :

Dituturkan oleh seorang karyawan kepada rekannya yang mempunyai hubungan sangat dekat antara satu dengan yang lain di ruang kerjanya. Terlihat Tuti menunjukkan rasa simpatinya kepada Ani yang baru saja mengabarkan kabar duka. Orang yang mampu memaksimalkan rasa simpatinya kepada orang lain akan dianggap orang yang santun.

\section{Efektifitas Berbahasa}

Bahasa Indonesia yang efektif sangat diperlukan agar komunikasi antar suku atau daerah di Indonesia dapat berlangsung dengan baik. Hal ini tentu akan berpengaruh terhadap persatuan bangsa Indonesia karena memiliki alat komunikasi yang bisa 
mempersatukan mereka. Penggunaan bahasa Indonesia yang efektif tentu akan membuat komunikasi yang lebih mudah serta dapat mencerminkan nilai-nilai pendidikan pada masyarakat bahasa dalam lingkungan yang terpelajar. Badudu (1995) menyatakan bahwa bahasa yang efektif akan mempermudah seseorang untuk memahami sesuatu yang disampaikan. Dengan kata lain, apa yang dimaksud oleh penulis atau penutur sama seperti apa yang dipahami oleh pembaca atau pendengar. Tulisan yang tidak efektif tentu akan membuat pembaca kesulitan dalam memahami kalimat yang dimaksud. Sehingga apa yang hendak disampaikan oleh penulis tidak akan diterima baik oleh pembaca.

Kalimat efektif adalah kalimat yang singkat, padat, jelas, lengkap dan dapat menyampaikan informasi secara tepat. Widjono (2007:160) menyatakan bahwa kalimat efektif dapat mengmunikasikan pikiran atau perasaan penulis atau pembicara kepada pembaca atau pendengar secara tepat. Kalimat dikatakan singkat karena hanya menggunakan unsur yang diperlukan saja. Setiap unsur kalimat benar-benar berfungsi. Sedangkan sifat padat mengandung makna sarat dengan informasi yang terkandung di dalamnya. Kalimat efektif dapat mengomunikasikan pikiran atau perasaan penulis atau pembicara kepada pembaca atau pendengar secara tepat. Dengan kalimat efektif, komunikasi penulis dan pembaca atau pembicara dan pendengar tidak akan menghadapi keraguan, salah komunikasi, salah informasi, atau salah pengertian. berikut :

Widjono (2007:161), mengemukakan ciri-ciri kalimat efektif antara lain sebagai

1. Keutuhan, kesatuan, kelogisan, atau kesepadanan makna dan struktur;

2. Kesejajaran bentuk kata, dan (atau) struktur kalimat secara gramatikal;

3. Kefokusan pikiran sehingga mudah dipahami;

4. Kehematan penggunaan unsur kalimat;

5. Kecermatan dan kesantunan;

6. Kevariasian kata, dan struktur sehingga menghasilkan kesegaran bahasa;

7. Ketepatan diksi;

8. Ketepatan ejaan.

\section{DATA DAN ANALISIS DATA}

Hasil penelitian ini meliputi dua tahap yaitu pelanggaran kesantunan berbahasa mahasiswa kepada dosen melalui tuturan pada aplikasi pesan whatsapp dan hubungan pelanggaran kesantunan berbahasa terhadap efektifitas penggunaan bahasa mahasiswa.

\section{Bentuk- bentuk pelanggaran kesantunan berbahasa mahasiswa STMIK Handayani Makassar}

Analisis bagian ini menggunakan teori prinsip kesantunan berbahasa Leech yang terdiri dari enam maksim. Peneltian ini mengambil sebanyak 50 tuturan yang kurang santun dalam interaksi mahasiswa dengan dosen pada aplikasi whatsapp. 50 tuturan tersebut diklasifikasi berdasarkan maksim yang dilanggarnya. Hasil penelitian menunjukkan bahwa pelanggaran terhadap prinsip kesantunan Leech meliputi maksim kebijaksanaan, maksim kedermawanan, maksim kesederhanaan, serta maksim pemufakatan atau kecocokan. Sedangkan maksim kesimpatian dan penghargaan tidak ditemukan adanya pelanggaran pada kedua maksim tersebut. Untuk lebih jelasnya, penulis uraikan hasil peneltian tersebut, berikut ini: 


\section{a. Pelanggaran Maksim Kebijaksanaan}

Maksim kebijaksanaan merupakan maksim yang paling banyak dilanggar. Pelanggaran maksim ini sebanyak 21 tuturan. Pelanggaran maksim kebijaksanaan ditandai dengan upaya memperkecil keuntungan orang lain dan memperbesar kerugian orang lain. Sebaliknya penutur ingin memkasimalkan keuntungan bagi diri sendiri dan memperkecil kerugian bagi diri sendiri. Berikut adalah beberapa komunikasi antara mahasiswa dengan dosen melalui aplikasi pesan whatsapp yang menunjukkan adanya pelanggarna terhadap prinsip kebijaksanaan.
[22] Dosen
: "Bawakan saya besok, TA nah!”
Mahasiswa
: "Di rumahta atau di kampus bu'?, karena ujiannya jam 11 besok."
Dosen
: "Di kampus maksud saya, tadi knp tdk hubungi ka?"
Mahasiswa
: "Oh iyye ibu, maaf sekali ibu."
Dosen
: "Saya tunggu tadi."
Mahasiswa
: "Iyye maaf ibu, darika tadi belanja ibu jadi saya lupami kabariki.
[27]Mahasiswa Maaf skli ini ibu."
Dosen
: “Assalamualaikum bu', bagaimana nilai mata kuliah saya belum masuk bu', tadi malam sy sudah hubungi dosennya?"
Mahasiswa : "Ibu Novi bu. Karena kebutuhan pindah bu."

Dalam konteks percakapan 22, pelanggaran terhadap prinsip kebijaksanaan ditandai pada kalimat tanya yang diutarakan oleh dosen yang menanyakan kenapa mahasiswa yang betindak sebagai anak bimbingannya tidak menghubungi dosen tersebut padahal dosen sudah menunggu. Yang kemudian ditambah dengan pernyataan dari mahasiswa bahwa dia tidak menghubungi dosen karena lupa disebabkan pergi berbelanja. Dalam hal konteks interaksi dengan dosen pernyataan seperti ini sangat merugikan bagi dosen dan menguntungkan mahasiswa. Pada situasi normal keadaan seperti ini biasanya berbalik, jika mahasiswa yang membutuhkan dosen dan diminta untuk menghubungi maka hal lain yang tidak terlalu mendesak akan dikesampingkan dahulu sebab kepentingan bersama dosen itu jauh lebih mendesak. Sehingga dosen merasa tersinggung dengan pernyataan itu yang mengakibatkan dosen tidak memberi respon lagi dengan pernyataan mahasiswa. Tentu saja ini sudah melanggar prinsip kebijaksanaan.

Dalam konteks percakapan 27 pelanggaran prinsip kebijaksanaan terlihat pada pernyataan mahasiswa yang menanyakan perihal nilai yang belum masuk padahal waktu penyetoran nilai memang belum sampai pada tenggat waktunya. Pertanyaan dan pernyataan tersebut melanggar maksim kebijaksanaan yang menyiratkan bentuk imperatif pada mitra tutur yang menyebabkan orang tersebut tidak memiliki pilihan lain selain menuruti apa yang dituturkan oleh mahasiswa.

\section{b. Pelanggaran Maksim Pemufakatan/Kecocokan}

Maksim pemufakatan/kecocokan adalah maksim yang paling banyak dilanggar setelah maksim kebijaksanaan. Pelanggaran maksim ini ditemukan sebanyak 17 tuturan. Pelanggaran maksim pemufakatan dalam interaksi dosen dan mahasiswa melalui aplikasi pesan whatsapp ditandai dengan upaya seseorang untuk memperkecil penyesuaian diri sendiri dan orang lain dan memperbesar ketidaksesuaian diri sendiri dan 
orang lain. Berikut adalah beberapa bentuk komunikasi anatara mahasiswa dan dosen melalui aplikasi pesan whatsapp yang melanggar maksim pemufakatan/kecocokan.

[13] Mahasiswa : "Assalamu Alaikum pak, maaf mengganggu pak mau bertanya, bagaimana caranya untuk mengganti kursus yang diikuti jadi client server, terima kasih."

Dosen : :Ini siapa?"

[30] Mahasiswa : "Assalamu Alaikum wr wb. Maaf mengganggu waktunya pak, saya Nur Faisah mahasiswa bimbingan skripsi bapak angkatan 2016. Apakah bisa saya bimbingan hari ini pak? Terima kasih sebelumnya pak."

Dosen : :Boleh."

Mahasiswa : "Di rumahta pak atau di luar pak?"

Dosen : :Faisah, di mana skrng?"

Mahasiswa : "Di kos pak."

Dosen : "Iya maksud saya kostnya di mana? Di Kalimantan atau di Merauke?"

Pada wacana 13 pelanggaran maksim pemufakatan terjadi akibat mahasiswa dan dosen tidak memiliki pemahaman yang sama terkait informasi sebelum mahasiswa menghubungi dosen. Dalam menghubungi dosen terdapat aturan yang perlu diketahui mahasiswa. Hal itu terbukti dengan jawaban dosen menanyakan "siapa" sebagai jawaban dari pertanyaan mahasiswa.

Pun hal itu terjadi pada wacana 30. Terlihat ada sedikit ketidakcocokan pemahaman yang menjadikan dosen menjadi sedikit emosi dengan jawaban mahasiswa sehingga menjawab tidak sesuai dengan apa yang dinyatakan oleh mahasiswa. Pada potongan percakapan yang dinyaatakan oleh mahasiswa "saya di kost pak", dijawab oleh dosen “"Iya maksud saya kostnya di mana? Di Kalimantan atau di Merauke?”, menandakan pelanggaran terhadap prinsip pemufakatan yang mengakibatkan dosen menjawab hal tersebut karena jawaban mahasiswa tidak sesuai dengan pertanyaan yang ditanyakan oleh dosen.

\section{c. Pelanggaran Maksim Kedermawanan}

Maksim yang paling banyak dilanggar selanjutnya adalah maksim kedermawanan, yaitu sebanyak 9 tuturan. Pelanggaran maksim kedermawanan dalam interaksi dosen dan mahasiswa melalui aplikasi pesan whatsapp ditandai dengan upaya seseorang untuk memperkecil kerugian diri sendiri dan memperbesar keuntungan diri sendiri. Perbedaan maksim kedermawanan dengan maksim kebijaksanaan adalah terletak pada fokusnya. Jika maksim kebijaksanaan berfokus pada orang lain maka maksim kedermawanan berfokus pada diri sendiri. Berikut adalah beberapa bentuk komunikasi anatara mahasiswa dan dosen melalui aplikasi pesan whatsapp yang melanggar maksim kedermawanan.

[16] Mahasiswa : :Kita yang pegang data-data mahasiswa PKL bu?"

Dosen : :PKL atau KKLP?" 
Mahasiswa : 'Data-data PKL bu', bisa kita kirimkan ka itu data-data bu'?, minta maaf bu' saya mintanya lewat chat bu' tidak minta secara langsung, itu penelitian ku bu' di kampus stmik handayani Makassar."

Dosen : :Masukkan dulu surat izin penelitian."

Mahasiswa : :Adaji surat izin penelitian ku bu', bisa ji to kita kirimkan ka bu'?"

Dosen : Tidak ada balasan

[20] Mahasiswa : "Assalamualaikum mam, saya Selbi Hardiansa, mohon maaf saya mau bertanya bgaimana soal nilaiku mam karena mauka pengurusan berkas magang mam dan nilai korespondensi bahasa Indonesiaku yang semester dua masih bermasalah."

Dosen : :Waalaikumsalam, besok saya di kampus, ada surat pengantarnya?"

Mahasiswa : "Surat pengantar yang bagaimana mam?"

Dosen : "Untuk perbaikan nilai?"

Mahasiswa : :Mam pernah dulu kita bilang cuman datang saja ke kampus."

Dosen : Tidak ada balasan

Pada wacana 16 pelanggaran terjadi karena petutur melakukan sesuatu yang tidak menghasilkan efek berupa tindakan diri sendiri dan membuat diri sendiri yang berkewajiban memberi keputusan kepada orang lain. Pernyataan tersebut ditunjukkan pada pernyataan mahasiswa "data-data PKL bu', bisa kita kirimkan ka itu data-data bu'?" dan pernyataan "adaji surat izin penelitian ku bu', bisa ji to kita kirimkan ka bu'?". Tidak adanya balasan dari dosen mengindikasikan bahwa dosen tersebut agak kesal dengan pertanyaan mahasiswa yang kesannya memaksakan apa yang menjadi kepentingannya. Tindakan ini sangat melanggar maksim kedermawanan yaitu membperbesar keuntungan diri sendiri. Selain itu pilihan kata yang digunakan menggunakan bahasa nonformal sehingga terkesan agak kurang santun.

Pada wacana 20 pelanggaran maksim kedermawanan terjadi akibat petutur membuat diri sendiri yang berkewajiban memberi keputusan kepada orang lain yang ditandai dengan pernyataan mahasiswa "Mam pernah dulu kita bilang cuman datang saja ke kampus". Pernyataan tersebut seolah menolak untuk mengikuti prosedur yang telah ditetapkan dalam pengurusan perbaikan nilai. Indikasinya dosen tidak membalas pesan tersebut sebagai akibat kekesalan sebab mahasiswa merasa dirinya pengambil keputusan untuk nilai yang akan diberikan.

\section{d. Pelanggaran Maksim Kesederhanaan}

Maksim ini merupakan maksim yang paling sedikit dilanggar, yaitu hanya ada 2 tuturan. Pelanggaran terhadap maksim kesederhanaan ditandai dengan upaya untuk memperkecil kritik pada diri sendiri dan memperbesar pujian bagi diri sendiri. Indikator terjadinya pelanggaran prinsip kesederhanaan antara lain menunjukkan kelebihan diri sendiri, menyombongkan diri, dan memamerkan kelebihan pada orang lain. Berikut adalah beberapa komunikasi antara mahasiswa dengan dosen melalui aplikasi pesan whatsapp yang menunjukkan adanya pelanggarna terhadap prinsip kesederhanaan.

[18]Dosen : :Banyak baca buku dan jurnal untuk nambah refernsi!"

Mahsiswa : "Saya suka membaca sih bu', tapi cepat bosannya kalu isinya ga ada romancex."

Dosen : "Membaca bukan hanya karena suka, tapi nambah pengetahuan."

Mahasiswa : "Masih banyak buku saya tapi sudah dimasukkan dalam tempat penyimpanan." 
Volume 6 Nomor 2

[19]Dosen : "Oke, terima kasih sudah niat membantu."

Mahasiswa: "Saya nggak tau bu kenapa nggak bisa akses."

Dosen : "Mungkin nda ikhlas, ibu cari orang lain yaa....:D"

Mahasiswa: "Saya ini mahasiswa paling tulus bu' :D."

Pada konteks percakapan 18 terlihat bahwa mahasiswa berupaya menunjukkan kelebihan diri sendiri. Pada pernyataan "saya suka membaca sih bu'." Dan pernyataan "masih banyak buku saya tapi sudah dimasukkan dalam tempat penyimpanan." Menunjukkan bahwa mahasiswa menunjukkan kelebihan diri sendiri dengan menonjolkan bahwa dia suka membaca dan masih banyak buku ditempat penyimpanan. Yang dibalas oleh dosen dengan mengatakan bahwa membaca bukan hanya karena suka tapi karena untuk menambah pengetahuan.

Pada wacana komunikasi 19 terlihat mahasiswa memperkecil kecaman diri sendiri dengan menunjukkan kelebihan diri sendiri. Pernyataan tersebut dapat ditemukan pada kalimat mahasiswa yang menyatakan "saya ini mahasiswa paling tulus bu'. Menyatakan diri sendiri tulus itu mengurangi nilai rasa kesopanan dan kurang merendahkan diri sehingga dapat dikatakan melanggar maksim kesederhanaan.

Tabel 1 Pelanggaran Prinsip Kesantuan

\begin{tabular}{|c|l|l|c|}
\hline No & \multicolumn{1}{|c|}{ Jenis Pelanggaran } & \multicolumn{1}{|c|}{ Nomor Data } & Jumlah \\
\hline 1 & Maksim Kebijaksanaan & $2,8,14,17,22,25,26,27,33,3$ & 21 \\
& & $6,37,38,39,40,43,44,45,46$, & \\
& & $47,48,49,50$ & 17 \\
\hline 2 & Maksim Pemufakatan & $1,4,5,6,9,10,12,13,23,24,28$, & \\
& & $30,31,32,35,41,42$ & 9 \\
\hline 3 & Maksim Kedermawanan & $3,7,11,15,16,20,21,29,34$ & 2 \\
\hline 4 & Maksim Kesederhanaan & 18,19 & \\
\hline
\end{tabular}

\section{Efektifitas Penggunaan Bahasa Mahasiswa STMIK Handayani Makassar}

Efektivitas penggunaan bahasa mahasiswa pada aplikasi pesan whatsapp yang ditemukan pada data dapat dijabarkan antara lain sebagai berikut:

\section{a. Keutuhan Kalimat}

Keutuhan kalimat ditandai dengan adanya kesepadanan struktur dan makna kalimat. Ketidakutuhan kalimat dapat kita lihat pada kalimat di bawah ini:

"Malam Pak, maaf mengganggu. Bagaimana cara ubah jenis kelaminnya ini?"

Selain tidak menggunakan bahasa formal, kalimat dalam kutipan percakapan di atas menunjukkan ketidakutuhan dalam penulisan sehingga makna yang ingin disampaikan oleh penutur tidak bisa terwakilkan oleh kalimat yang dipilih, sehingga terkesan tidak utuh. Informasi yang diterima jadi kurang lengkap. Frasa ubah jenis kelamin tidak disertai objek sehingga rancu untuk maknanya. Apakah yang dimaksud oleh penutur dengan mengubah jenis kelamin. Kalimat yang benar adalah

"Selamat malam Pak, maaf mengganggu waktunya. Saya ingin bertanya, bagaimana cara mengubah pilihan jenis kelamin pada ijazah karena jenis kelamin tidak sesuai Pak." 


\section{b. Kelogisan}

Kelogisan adalah bahwa ide kalimat itu dapat diterima oleh akal dan penulisannya sesuai dengan ejaan yang berlaku. Ketidaklogisan kalimat dapat dilihat pada kalimatkalimat di bawah ini:

"Ibu kapan saya bisa menghadap ujian ibu?"

Kalimat di atas menunjukkan ketidaklogisan karena menyatakan "menghadap ujian" yang mengindikasikan subjek ingin menghadap pada ujian yang tidak mungkinl dilakukan. Kalimat yang benar adalah :

"Ibu kapan saya bisa menghadap pada ibu untuk melaksanakan ujian ibu?"

Ketidaklogisan juga terjadi pada kalimat di bawah ini:

“Assalamu Alaikum bu', saya Ade Rahmdhani, mahasiswa semester pendek"

Kalimat tersebut tidak logis karena menyatakan "mahasiswa semester pendek". Kalimat yang benar adalah:

“Assalamu Alaikum bu', saya Ade Rahmadhani, mahasiswa yang mengikuti program semester pendek"

Begitupun dengan kalimat di bawah ini, dapat kita lihat:

"Iya sudah berubah bu' tapi masih ada beberapa mata kuliah yang bertabrakan."

Pada kalimat "kuliah yang bertabrakan" menunjukkan ketidaklogisan, karena yang bertabrakan biasanya adalah mobil atau benda yang bersifat keras. Bertabrakan dalam Kamus Besar Bahasa Indonesia adalah bertubrukan, terbentur dan membentur. Kalimat yang benar adalah:

"Iya sudah berubah bu' tapi masih ada beberapa mata kuliah yang jadwalnya bersamaan."

\section{c. Ketepatan Diksi}

Dalam berkomunikasi ketapatan diksi atau pilihan kata sangatlah menentukan keefektifan suatu aktivitas komunikasi. Dalam penelitian ini kalimat yang tidak memenuhi syarat ketepatan diksi dapat dilihat pada kalimat berikut:

"Assalamu Alaikum pak, maaf mengganggu pak mau bertanya, bagaimana caranya untuk mengganti kursus yang diikuti jadi client server, terima kasih."

Kata kursus padakalimat di atas tidak tepat sebab terlihat pada percakapan bahwa situasi ini dilakukan antara mahasiswa dan dosen sehingga pemilihan kata kursus itu tidak tepat dan membuat makna dari kalimat yang diutarakan menjadi kabur. Selain itu untuk mata kuliah pengganti, tidak disebutkan sehingga pembaca sulit menafsirkan maknanya. Kalimat yang benar adalah:

"Assalamu Alaikum pak, maaf mengganggu pak mau bertanya, bagaimana caranya untuk mengganti mata kuliah (sebutkan nama mata kuliah yang ingin diganti) yang diikuti jadi client server, terima kasih." 
Jurnal Onoma: Pendidikan, Bahasa dan Sastra

Volume 6 Nomor 2

\section{Simpulan}

Pelanggaran terhadap prinsip kesantunan Leech meliputi 4 maksim. Pelanggaran secara berturut-turut dilakukan terhadap maksim kebijaksanaan, maksim pemufakatan, maksim kedermawanan, dan maksim kesederhanaan. Pelanggaran maksim ini pada proses komunikasi mahasiswa melalui pesan whatsapp menandakan bahwa masih ada indikasi yang membuat mahasiswa tidak santun dalam melakukan komunikasi dengan dosen dalam media online. Pelanggaran kesantunan mahasiswa mempengaruhi keefektifan berbahasa mahasiwa pada proses komunikasi, dan keefektifan itu dibahas dalam tiga jenis yaitu keutuhan kalimat, kelogisan dan ketepatan diksi. 
Jurnal Onoma: Pendidikan, Bahasa dan Sastra

ISSN 2443-3667 (print)

PBSI FKIP Universitas Cokroaminoto Palopo

ISSN 2715-4564 (online)

Volume 6 Nomor 2

\section{Daftar Pustaka}

Badudu, J.S. 1995. Cakrawala Bahasa Indonesia. Jakarta: PT. Gramedia.

Budiwati Tri Rina. 2017. Kesantunan Berbahasa Mahasiswa dalam Berinetraksi dengan Dosen di Universitas Ahmad Dahlan: Ananlisis Pragmatik. Yogyakarta: UAD

Chaer, Abdul. 2003. Linguistik Umum. Jakarta: Rieneka Cipta.

Depdiknas. 2008. Kamus Besar Bahasa Indonesia (Edisi Revisi). Jakarta : Balai Pustaka.

Departemen Pendidikan Nasional. 2008. Kamus Besar Bahasa Indonesia Edisi Keempat. Jakarta : Diknas.

Grice, H. Paul. 1991. Logic and Conversation dalam Davis S.(Ed.) Pragmatics : A Readee .New York: Oxford University Press.

Gunawan, Fahmi. Wujud Kesantunan Berbahasa Mahasiswa Terhadap Dosen Di STAIN Kendari: Kajian Sosiopragmatik. Journal Arbitrer, Vol 1 No 1 Oktober 2013

Meleong, Lexy. 2004. Metodologi Penelitian Kualitatif. Bandung: PT Remaja Rosdakarya.

Tarigan, Henry Guntur. 1990. Pengajaran Pragmatik. Bandung: Angkasa

Rahardi, Kunjana. 2002. Pragmatik: Kesantuan Imperatif Bahasa Indoensia. Jakarta: Erlangga.

Leech, Geoffrey. 2011. Prinsip-prinsip Pragmatik. Jakarta: Universitas Indonesia

Leech, Geoffrey. 1993. Prinsip-prinsip Pragmatik. Jakarta : Universitas Indonesia (UI Press).

Meleong, Lexy. 2004. Metodologi Penelitian Kualitatif. Bandung:PT Remaja Rosdakarya.

Mulyana, Deddy. 2001. Metodologi Penelitian Kualitatif. Bandung: PT. Remaja Rosdakarya

Rahardi, Kunjana. 2005. Pragmatik Kesantunan Imperatif Bahasa Indonesia. Jakarta: Erlangga.

Samosir, Astuti. Kesantunan Bahasa Whatsapp Mahasiswa Terhadap Dosen Prodi Pendidikan Bahasa Indonesia di Universitas Indraprasta PGRI. Journal Akrabjuara, Vol 4 No 2 Mei 2019.

Sudaryanto. 1993. Metode dan Aneka Teknik Analisis Bahasa: Pengantar Penelitian Wahana Kebudayaan Secara Linguistis. Yogyakarta : Duta Wacana University Press.

Widjono, Hs. 2007. Bahasa Indonesia Mata Kuliah Pengembangan Kepribadian di Perguruan Tinggi (Rev). Jakarta: Grasindo.

Yassi, Abdul Hakim. 2017. Usia dan Strategi Kesantunan Pada Budaya Bahasa-bahasa di Sulawesi Selatan: Kritik Terhadap Teori Kesantunan Brown \& Levinson. Prosiding Seminar Nasional Linguistik (SEMIOTIK). Hal:13

Yule, George. 2006. Pragmatik. Yogyakarta : Pustaka Pelajar (Terjemahan) 